\title{
УДК 502:616+591.131.3
}

М. В. Маркіна, О. К. Вяткін, В. П. Ляшенко, А. І. Руденко

Дніпропетровський регіональний державний науково-технічний ценнтр стандартизації, метрології та сертифікації

Дніпропетровський національний університет ім. Олеся Гончара Інститут гастроентерологї АМН Украӥни

\section{КАТІОННИЙ СКЛАД СЛИНИ У ЛЮДЕЙ ІЗ ПОРУШЕННЯМИ ДІЛЬНОСТІ ШЛУНКОВО-КИШКОВОГО ТРАКТУ}

Розглянуто зв'язок між патологіями шлунково-кишкового тракту та змінами концентрацій мікроелементів у слині людини. Показано зменшення вмісту катіонного складу у слині при формуванні та розвитку патологічного процесу у шлунково-кишковому тракті.

М. В. Маркина, О. К. Вяткин, В. П. Ляшенко, А. И. Руденко

Днепропетровский региональный государственный научно-технический центтр стандартизации, метрологии и сертификации

Днепропетровский национальный университет им. Олеся Гончара Институт гастроэнтерологии АМН Украины

\section{КАТИОННЫЙ СОСТАВ СЛЮНЫ У ЛЮДЕЙ С НАРУШЕНИЯМИ ДЕЯТЕЛЬНОСТИ ЖЕЛУДОЧНО-КИШЕЧНОГО ТРАКТА}

Рассмотрена связь между патологиями желудочно-кишечного тракта и изменениями концентраций микроэлементов в слюне человека. Показано уменышение содержания катионного состава в слюне при формировании и развитии патологического процесса в желудочно-кишечном тракте.

M. V. Markina, O. V. Vyatkin, V. P. Lyashenko, A. I. Rudenko

Dnipropetrovsk Regional State Research-Technical Centre for Standardization, Metrology and Certification Oles' Gonchar Dnipropetrovsk National University Institute of Gastroenterology AMS Ukraine

\section{SALIVA CATIONS COMPOSITION IN HUMANS WITH THE DISORDERS OF GASTROINTESTINAL TRACT ACTIVITY}

Connection between the pathologies of alimentary canal and the changes of concentrations of microelements in human saliva is under consideration. The decrease of the cations content in saliva under forming and developing the pathological process in gastrointestinal tract is shown.

\section{Вступ}

Значна поширеність захворювань гастродуоденальної системи, що викликає серйозну загрозу для життя та здоров'я людини, зумовлює необхідність і важливість розробки способів діагностики, методів лікування, а в ряді випадків і попередження прогресування захворювань. При патології порушуються як поодинокі процеси, так і сис- 
темна їх організація. Це є принциповим критерієм розмежування патології від передпатології [1-3]. Із біологічного погляду організм являє собою саморегулювальну систему, корисними адаптивними результатами якої є, в першу чергу, електролітичні та гомеостатичні показники, що забезпечують різноманітні сторони метаболічних процесів.

Дослідження та виявлення закономірностей елементного статусу (показника, який оцінює кількість хімічних елементів, що містяться в організмі людини, тобто стан їх дефіциту, надлишку чи дисбалансу) різних груп людей дозволяс розробити рекомендації з метою профілактики виникнення захворювань [7].

Велике значення для діагностики патологій шлунково-кишкового тракту має характеристика хімічного стану слини, рідини, яка $€$ найбільш недооціненою та найменш вивченою з усіх рідин організму, а за значенням - найвпливовішою в життєдіяльності людини. Зіставлення даних щодо концентрації хімічних елементів у слині та плазмі крові може дозволити виявити певні властивості чи навіть закономірності для конкретних груп захворювань, що відкриває можливості використання в клінічних і експериментальних дослідженнях проб слини, доступніших за проби крові [8; 9].

Перевагами даного об'єкта досліджень порівняно з кров'ю є безболісне збирання слини, простота процедури, зручність, відсутність ризику внесення інфекції, травми шкіри чи стінок судин, адекватності концентрації речовини. У клінічній практиці нині домінує визначення загального складу хімічних елементів. Проте визначення іонізованої фракції певного елемента має більше діагностичне значення [5; 10; 14].

Мета дослідження полягала у виявленні можливих кореляційних взаємозв'язків між катіонним складом слини та порушеннями діяльності шлунково-кишкового тракту за допомогою сучасного методу аналізу - системи капілярного електрофорезу.

\section{Матеріал і методи досліджень}

У дослідженнях брали участь жінки, вік яких належить до першого періоду зрілого віку згідно зі схемою вікової періодизації онтогенезу людини та складає діапазон 21-35 років. Жінки із захворюваннями органів травлення залежно від діагностичних даних, установлених за допомогою інструментальних методів аналізу, були поділені на групи: I - контрольна (20 жінок), до складу входили практично здорові жінки; II - постхоліцистектомічний синдром (ПХЕС), секреція гіперацидна (20 жінок); III - ПХЕС, секреція анацидна (20 жінок); IV - неспецифічний виразковий коліт (НBК), секреція гіперацидна (15 жінок); V група - НВК, секреція анацидна (15 жінок).

Слину для аналізу відбирали в один і той же час, натще. Для ідентифікації та кількісного визначення катіонів у слині використовували метод капілярного електрофорезу із застосуванням приладу «Капель 103Р» фірми «Люмэкс» (Росія, 2000).

За допомогою приладу з фотометричним детектором і довжиною хвилі 253,7 нм реєстрували неорганічні катіони з використанням так званого непрямого детектування: до складу електроліту вводили невелику концентрацію речовини, що поглинається при потрібній довжині хвилі. При визначенні катіонів натрію, кальцію, калію та магнію використовували добавку катіонів ароматичних амінів - катіон протонованого бензимідазолу $[11 ; 12 ; 15]$.

Кількісне визначення вмісту катіонів у слині проводили за допомогою градуювального графіка та методу добавок. Для побудови градуювальних графіків готували серії стандартних розчинів методом розведення визначених порцій вихідних розчинів буфером у пробірках Епендорфа об'ємом 1,5 cм³. Для кожної концентрації реєстрували в оптимальних умовах електрофореграми та за ними обчислювали середнє значення площі піку із трьох вимірювань. Для точної побудови градуювальної залежності засто- 
совували лінійну регресію методом найменших квадратів $[4 ; 16]$. Для запису та обробки отриманих результатів у вигляді електрофореграм використовували програму «Мультихром». Результати оброблені статистично методом парних порівнянь.

\section{Результати та їх обговорення}

У контрольній групі масова концентрація натрію складала 17,82 $\pm 2,10$ ммоль/л, що відповідає нормі (6,5-21,7 ммоль/л) [5]. Визначення вмісту натрію у слині людей із жовчокам'яною хворобою та з патологією кишечника показало, що в II, III та V групах спостерігається достовірне $(p<0,05$ та $p<0,001)$ відносно контролю зниження концентрації даного елемента порівняно з даними контрольної групи (табл.). Вміст натрію в слині IV групи був на рівні контролю та входив у діапазон норми (6,5-21,7 ммоль/л) [5; 13].

Концентрація катіонів натрію, калію, магнію та кальцію у слині жінок (ммоль/л)

Табличя

\begin{tabular}{|l|c|c|c|c|c|}
\hline \multicolumn{1}{|c|}{ Елемент } & I група & II група & III група & IV група & V група \\
\hline Натрій & $17,82 \pm 2,10$ & $9,16 \pm 2,89^{*}$ & $5,64 \pm 1,06^{* *}$ & $18,33 \pm 5,20$ & $4,29 \pm 1,36^{* *}$ \\
\hline Калій & $21,91 \pm 1,79$ & $9,38 \pm 1,24^{* *}$ & $8,38 \pm 1,10^{* *}$ & $9,30 \pm 2,70^{*}$ & $9,69 \pm 2,65^{*}$ \\
\hline Кальцій & $0,98 \pm 0,05$ & $0,21 \pm 0,05^{* *}$ & $0,09 \pm 0,03^{* *}$ & $0,22 \pm 0,07^{* *}$ & $0,49 \pm 0,19^{*}$ \\
\hline Магній & $0,57 \pm 0,20$ & $0,27 \pm 0,01^{* *}$ & $0,26 \pm 0,02^{*}$ & $0,18 \pm 0,02^{*}$ & $0,27 \pm 0,01^{*}$ \\
\hline
\end{tabular}

Примітки: * $-p<0,05, * *-p<0,001$ відносно контролю.

Концентрація калію в контрольній групі складала 21,91 $\pm 1,79$ ммоль/л, що відповідає нормі (11,8-27,6 ммоль/л) для людей даної статі та віку [5]. При дослідженні слини жінок II-V груп вміст калію був меншим порівняно 3 даними контрольної групи і складав відповідно 42,8, 38,3, 42,4 та 44,2 \%. Тобто співвідношення значень концентрації калію в II, IV та V групах було приблизно однаковим. У II та III групах спостерігалось достовірне зменшення концентрації калію відносно контролю при $p<0,001$, а в IV та V групах - достовірне зменшення при $p<0,05$. Вміст калію у слині досліджених II-V груп був значно меншим нижньої межі норми, яка складає 11,8 ммоль/л.

У контрольній групі вміст кальцію складав $0,98 \pm 0,13$ ммоль/л, що відповідає нормі (1-2 ммоль/л) [5; 6]. Визначення вмісту кальцію у слині людей із постхолецистектомічним синдромом і з патологією кишечника показало, що в II-V групах спостерігається достовірне зменшення концентрації порівняно 3 контролем, а також те, що всі концентрації кальцію у дослідних групах були набагато менші нижнього значення норми. Мінімальний рівень концентрації кальцію у слині зареєстровано у людей III групи (ПХЕС, секреція анацидна) - 0,09 $\pm 0,03$ ммоль/л, що відповідає 9,2 \% контролю. У V групі (у людей з анацидною секрецією при неспецифічному виразковому коліті) вміст $C a^{2+}$ порівняно 3 даними контролю складає 50,0 \%. У групах досліджених людей із гіперацидною секрецією при НВК і ПХЕС вміст кальцію у слині був відповідно 22,5 та 21,4 \% відносно контрольної групи.

Що стосується магнію у слині всіх досліджених, то в контрольній групі його концентрація складала $0,57 \pm 0,20$ ммоль/л (при нормі 0,08-0,53 ммоль/л), а при патологіях вміст магнію значно знижувався порівняно з даними контролю, хоч і входив до діапазону норми. Зниження концентрації магнію в усіх групах досліджених людей було достовірним порівняно $з$ даними контролю, а саме в II групі $p<0,001$ відносно контролю, а в III-V групах $-p<0,05$. Мінімальне значення спостерігалось в IV групі (НВК, секреція гіперацидна), що складало 31,6 \% від контролю. 
При аналізі даних щодо вмісту кальцію та магнію у слині досліджених спостерігався деякий взаємозв'язок між цими характеристиками. При анацидній секреції в III та V групах (при ПХЕС та НВК) відмічається розходження значень концентрації магнію та кальцію, у той час як при гіперацидній секреції в II та IV групах (при ПXЕС i захворюваннях кишечника) вміст $\mathrm{Ca}^{2+}$ та $\mathrm{Mg}^{2+}$ приблизно однаковий. У контрольній групі також спостерігалась розбіжність значень концентрацій магнію та кальцію, набагато більша, ніж при неспецифічному виразковому коліті (V група) та при постхолецистектомічному синдромі (III група). Крім того, при НВК у V групі розходження вмісту магнію та кальцію більше, ніж при ПХЕС у III групі, а концентрації $\mathrm{Ca}^{2+}$ та $\mathrm{Mg}^{2+}$ при гіперацидній секреції у людей із неспецифічним виразковим колітом у IV групі ближчі, ніж у III групі при постхолецистектомічному синдромі 3 гіперацидною секрецією.

Таким чином, при неспецифічному виразковому коліті відмічається явище прямої залежності між секрецією та вмістом магнію та кальцію (кальцію набагато більше, ніж магнію). При постхолецистектомічному синдромі з анацидною секрецією (III група) відмічається обернена залежність між секрецією та вмістом магнію та кальцію (магнію більше, а кальцію набагато менше).

Концентрація кальцію та калію в ІІІ групі (ПХЕС, секреція анацидна) значно менша мінімального значення норми, проте в II, IV, V групах вміст у слині калію та кальцію взагалі менший за норму.

Знижений вміст калію у слині може свідчити про наявність астенії (фізичного виснаження, перевтоми), ризику порушення обмінних процесів, розвитку ерозивних утворень у слизових оболонках, зниження працездатності, а також порушення нервовом'язової провідності.

Співвідношення концентрацій натрію та калію в слині всіх досліджених людей різне, але можна спостерігати також певні закономірності. У контрольній групі вміст калію у слині вищий, ніж натрію. Збільшення концентрації калію у слині після механічного стимулювання, певно, може відповідати підвищенню його вмісту в крові у результаті дегідратації, виходу іонів $K^{+} 3$ еритроцитів та «депо». Також і в групах 3 анацидною секрецією при НВК та ПXЕС (III, V) спостерігалось розходження між концентраціями калію та натрію (калію більше, натрію менше). У IV групі відмічаємо протилежну картину. А у II групі, взагалі, значення калію та натрію приблизно збігаються.

Тобто при гіперацидній секреції за умов неспецифічного виразкового коліту та постхоліцистектомічного синдрому (II, IV групи) картина змін концентрацій елементів $\mathrm{Na}^{+}$та $K^{+}$різна та неоднозначна. При анацидній секреції (III та $\mathrm{V}$ групи) співвідношення концентрацій калію та натрію подібне: $K^{+}$більше, $\mathrm{Na}^{+}$менше. При патології НВК розходження між концентраціями калію та натрію більше, ніж при ПХЕС. При НВК масова концентрація калію 9,69 $\pm 2,65$, натрію $-4,29 \pm 1,36$ ммоль/л, а при ПХЕС вміст калію - 8,38 $\pm 1,10$, натрію $-5,64 \pm 1,06$ ммоль/л. Із наведених даних бачимо, що при патології кишечника вміст калію більший, а концентрація натрію менша порівняно з показниками ІІІ групи (патологія ПХЕС).

Якщо розглядати слину як похідну плазми крові, можна припустити, що зміни вмісту катіонів у слині певною мірою відображають їх зрушення в крові. У свою чергу, збільшення вмісту натрію у слині, на наш погляд, може відображати підвищення його концентрації в крові, що також є «пристосувальною реакцією організму», спрямованою на підтримання оптимальних для метаболізму величин осмотичного тиску та об'єму циркулюючої крові. Активна реабсорбція іонів $\mathrm{Na}^{+}$у слинних протоках пов'язана з впливом альдостерону $[2 ; 3 ; 17]$. 
На відміну від натрію концентрація калію у слині протягом усіх досліджень фактично була незмінною та залишалась зниженою у представників усіх груп, що може відбуватися внаслідок стабілізації вмісту елемента в крові. Можна припустити, що зменшення концентрації калію у слині досліджених людей із патологічними процесами в шлунково-кишковому тракті у більшості випадків може відповідати зменшенню його вмісту в крові та мати зв' язок з альдостероновим ефектом.

Отримані результати можуть свідчити, що при розвитку патологічних процесів у шлунково-кишковому тракті відбувається зміна секреції перш за все тих компонентів слини, які беруть участь у гомеостатичних реакціях, а саме катіонів, виділення яких може мати значення при аферентації з рецепторів ротової порожнини і таким чином впливати як на систему травлення, так і на організм у цілому.

Аналіз вмісту натрію та калію у слині дозволяє оцінити співвідношення тонусу симпатичного та парасимпатичного відділів вегетативної нервової системи. Можна припустити, що співвідношення концентрацій натрію та калію у слині характеризують функціональний стан водно-електролітного обміну регулювальних систем [8].

Тенденція зменшення відносно норми вмісту калію, кальцію, частково натрію та зниження концентрації магнію відносно даних контролю у слині досліджених жінок свідчить про зниження протекторного впливу слини на шлунково-кишковий тракт і відображає низький вміст даних металів в організмі.

Поглиблене дослідження взаємозв'язків допоможе детальніше зіставляти стан електролітного балансу ротової порожнини з активністю секреторних залоз нижче розташованих відділів шлунково-кишкового тракту та може бути одним із діагностичних тестів оцінки діяльності останніх.

\section{Висновки}

Виявлено взаємозв'язок між концентрацією іонів $\mathrm{Na}^{+}$та $\mathrm{K}^{+}$у слинних залозах, зменшення вмісту калію, кальцію, магнію у слині досліджених порівняно з контролем, а також концентрації натрію у II, III, V групах. Результати аналізу свідчать про наявність вираженої видільної функції слинних залоз і патологічних явищ у шлунковокишковому тракті. Отримані дані щодо вмісту кальцію, калію, натрію та магнію у слині при деяких захворюваннях шлунково-кишкового тракту залежно від ступеня та глибини враження слизових оболонок можуть свідчити про значні порушення секреції та виділення мікроелементів.

\section{Бібліографічні посилання}

1. Горшков В. А. Кислотозависимые заболевания и кризис функциональных методов исследования желудка // Сучасна гастроентерологія. - 2002. - № 3. - С. 7-12.

2. Хвороби органів травлення (діагностика і лікування) / П. Я. Григор'єв, Є. М. Стародуб, Є. П. Яковенко та ін. - Тернопіль : Укрмедкнига, 2000. - 448 с.

3. Дегтярева И. И. Заболевания органов пищеварения. - К., 1999. - 312 с.

4. Комарова Н. В. Практическое руководство по использованию систем капиллярного электрофореза «Капель» / Н. В. Комарова, Я. С. Каменцев. - СПб. : Веда, 2006. - 212 с.

5. Педанов Ю. Ф. Лабораторные показатели. Нормы взрослого человека. - Одесса, 1992. - 89 с.

6. Руководство по капиллярному электрофорезу / Лекции Х. Энгельгардта. Научный совет Российской академии наук по хроматографии. - М., 1996. - С. 45.

7. Слесарев В. И. Основы Химии живого. - СПб. : Химиздат, 2000. - 529 с.

8. Харченко Н. В. Клиническая гастроэнтерология. - К., 2000. - 446 с.

9. Шубин А. А. Неорганическая химия. Химия элементов / А. А. Шубин, Г. В. Нужная. - Донецк, 2003. - 324 c. 
10. Altria K. D. Capillary Electrophoresis Guidebook: Principles, Operation and Applications. - NJ : Humana Press, Totowa, 1996. - 349 p.

11. Baker D. R. Capillary Electrophoresis. - NY : John Wiley \& Sons Ltd, 1995. - 240 p.

12. Camilleri P. Capillary Electrophoresis: The Teory and Practice. - Boca Raton, FL : CRC Press, 1998. - 552 p.

13. Kuhn R. Capillary Electrophoresis Principles and Practice / R. Kuhn, S. Hoffstetter-Kuhn. - NY : Springer-Verlag, 1993. - 300 p.

14. Modlin I. M. Acid Related Diseases (Biology and Treatment) / I. M. Modlin, G. Sachs. - SchnetzorVerlad GmbHD-Konstanz, 1998. - 368 p.

15. Righetti P. G. Capillary Electrophoresis in Analytical Biotechnology. - Boca Raton: CRC Press, 1996. $-551 \mathrm{p}$.

16. Wehr N. Capillary Electrophoresis of Proteins / N. Wehr, R. Rodrigue-Diaz, M. Zhu. - NY : Marsel Dekker, 1998. - 368 p.

17. Westermeier R. Electrophoresis in Practice. - Wiley-VCH, $2001-368$ p.

Надійшла до редколегії 20.02.2010 